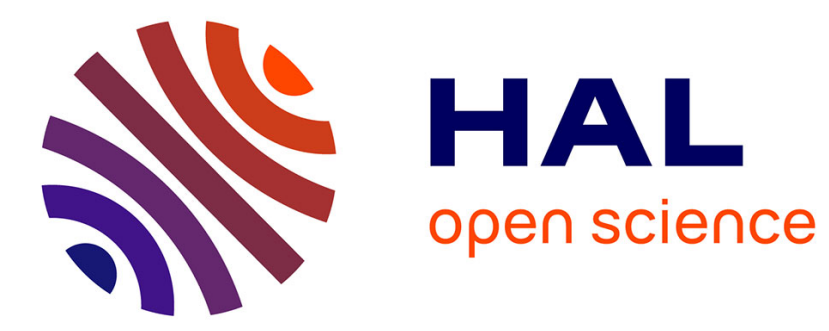

\title{
Improvement of barrier properties of a hybrid sol-gel coating by incorporation of synthetic talc-like phyllosilicates for corrosion protection of a carbon steel
}

Karine Joncoux-Chabrol, Jean-Pierre Bonino, Marie Gressier, Marie-Joëlle Menu, Nadine Pébère

\section{To cite this version:}

Karine Joncoux-Chabrol, Jean-Pierre Bonino, Marie Gressier, Marie-Joëlle Menu, Nadine Pébère. Improvement of barrier properties of a hybrid sol-gel coating by incorporation of synthetic talc-like phyllosilicates for corrosion protection of a carbon steel. Surface and Coatings Technology, 2012, vol. 206, pp. 2884-2891. 10.1016/j.surfcoat.2011.12.017 . hal-00837745

\section{HAL Id: hal-00837745 \\ https://hal.science/hal-00837745}

Submitted on 24 Jun 2013

HAL is a multi-disciplinary open access archive for the deposit and dissemination of scientific research documents, whether they are published or not. The documents may come from teaching and research institutions in France or abroad, or from public or private research centers.
L'archive ouverte pluridisciplinaire HAL, est destinée au dépôt et à la diffusion de documents scientifiques de niveau recherche, publiés ou non, émanant des établissements d'enseignement et de recherche français ou étrangers, des laboratoires publics ou privés. 


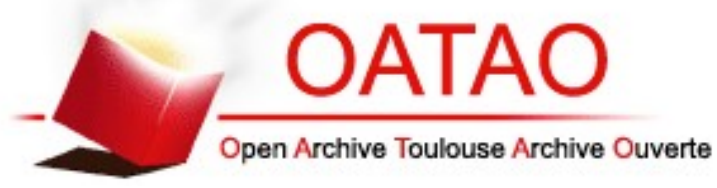

\section{Open Archive Toulouse Archive Ouverte (OATAO)}

OATAO is an open a ccess repository that collects the work of Toulouse researchers and makes it freely available over the web where possible.

This is an author-deposited version published in: http://oatao.univ-toulouse.fr/ Eprints ID: 5456

To link to this article: DOI: $10.1016 /$ j.surfcoat.2011.12.017

URL: http://dx.doi/10.1016/j.surfcoat.2011.12.017

\section{To cite this version:}

Joncoux-Chabrol, Karine and Bonino, Jean-Pierre and Gressier, Marie and Menu, Marie-Joëlle and Pébère, Nadine Improvement of barrier properties of a hybrid sol-gel coating by incorporation of synthetic talc-like phyllosilicates for corrosion protection of a carbon steel. (2012) Surface and Coatings Technology, vol. 206 . pp. 2884-2891. ISSN 0257-8972

Any correspondence concerning this service should be sent to the repository administrator: staff-oatao@listes.diff.inp-toulouse.fr 


\title{
Improvement of barrier properties of a hybrid sol-gel coating by incorporation of synthetic talc-like phyllosilicates for corrosion protection of a carbon steel
}

\author{
Karine Joncoux-Chabrol ${ }^{\mathrm{a}, \mathrm{b}}$, Jean-Pierre Bonino ${ }^{\mathrm{b}}$, Marie Gressier ${ }^{\mathrm{b}}$, Marie-Joëlle Menu ${ }^{\mathrm{b}}$, Nadine Pébère ${ }^{\mathrm{a}, *}$ \\ a Université de Toulouse, CIRIMAT, UPS/INPT/CNRS, ENSIACET, 4 Allée Emile Monso BP 44362, 31030 Toulouse Cedex 4, France \\ ${ }^{\mathrm{b}}$ Université de Toulouse, CIRIMAT, UPS/INPT/CNRS, 118 Route de Narbonne, 31062 Toulouse Cedex 9, France
}

Keywords:

Talc-like phyllosilicates

Sol-gel coatings

Carbon steel

Electrochemical impedance spectroscopy

Barrier properties

Corrosion protection

\begin{abstract}
A B S T R A C T
Sol-gel coatings for corrosion protection of metals are a good alternative to toxic chromate treatments. The present work focussed on the incorporation of inorganic fillers in a sol-gel coating to improve the barrier properties of the film. Talc-like phyllosilicates obtained by hydrothermal synthesis at $160{ }^{\circ} \mathrm{C}, 260{ }^{\circ} \mathrm{C}$ and $350^{\circ} \mathrm{C}$, called $\mathrm{T}_{160}, \mathrm{~T}_{260}$ and $\mathrm{T}_{350}$ respectively, were selected as inorganic fillers. The synthetic materials showed talc lamellar structure but, in contrast with natural talc, their smaller size (about $300 \mathrm{~nm}$ ) and their hydrophilic character allowed easier dispersion of the particles in the sol-gel matrix. Electrochemical impedance measurements performed on the sol-gel coatings deposited on XC35 carbon steel showed that the incorporation of $\mathrm{T}_{260}$ and $\mathrm{T}_{350}$ at a concentration of $20 \mathrm{~g} \mathrm{~L}^{-1}$ strongly enhanced the barrier properties of the coating by comparison with the filler-free system. As a consequence, the corrosion protection of the metal substrate was improved.
\end{abstract}

\section{Introduction}

Sol-gel coatings are good alternatives to chromate treatments for corrosion protection of metals. Their main action is to act as physical barriers against aggressive environments. The first studies were focussed on the formation of pure inorganic sol-gel films [1,2] and have shown that, to obtain dense coatings, the treatment temperature after deposition must be above $400^{\circ} \mathrm{C}$, which implies large energy consumption. Moreover, it was difficult to develop thick coatings without cracks. In 2004, Ono et al. [3] showed that the incorporation of an organic compound in the matrix led to more flexible and denser films that enabled thicker films to be made without cracking. Also, heat treatment temperature can be lowered after the sol deposition. Hence, hybrid sol-gel coatings have been widely developed. Van Ooij et al. [4] and Wang et al. [5] reviewed recent advances made with this technology.

Moreover, different studies have shown that the incorporation of clays in polymeric matrices can significantly improve their barrier properties due to the lamellar structure which increases the diffusion path length [6-10].

The aim of the present study is to improve the barrier properties of a particle-filled sol-gel coating. Talc was chosen as a filler candidate. The natural mineral is currently used as a filler to reinforce barrier properties of polymer [11-13]. Natural talc is a magnesium silicate of formula $\mathrm{Si}_{4} \mathrm{Mg}_{3} \mathrm{O}_{10}(\mathrm{OH})_{2}$. The ideal talc lamellar structure, described by several authors, is composed of elementary sheets stacked

\footnotetext{
* Corresponding author. Tel.: + 33534323423.

E-mail address: nadine.pebere@ensiacet.fr (N. Pébère).
}

on top of one another $[14,15]$. Each is made up of a layer of magnesium-oxygen/hydroxyl octahedral sandwiched between two layers of silicon-oxygen tetrahedral. The lamellar structure confers excellent barrier properties to natural talc. The basal faces of talc, corresponding to about $90 \%$ of the total surface [16], contain siloxane bonds $(\mathrm{Si}-\mathrm{O}-\mathrm{Si})$ - hydrophobic and inert - whereas the edge faces, composed of $\mathrm{Si}-\mathrm{OH}$ and $\mathrm{Mg}-\mathrm{OH}$ bonds, are hydrophilic and reactive. Therefore, talc is hydrophobic and inert, and its dispersion into aqueous sol and, as a consequence its incorporation in sol-gel coatings, is difficult. Recently, Martin et al. [17] have synthesised, by a hydrothermal process, talc-like phyllosilicates of nanometric size which thus present a more significant contribution of edge faces. In a previous work [18], the influence of the hydrothermal synthesis temperature on the structure, the morphology and the physicochemical characteristics of talc-like phyllosilicates was investigated. The minerals synthesised have the talc structure but they also contain stevensite structures; stevensite is a magnesium silicate which has the same chemical composition as talc but presents vacancies in the octahedral sites compensated for by the presence of cations in the interfoliar spaces. The proportion of stevensite structures in the sheets decreases when the hydrothermal synthesis temperature increases, which has a strong influence on the structure and morphology of the material. The hydrophilic character of the particles and the significant specific surface area of talc-like phyllosilicates compared to that of natural talc have been quantified [18]. These two physicochemical characteristics are linked to the quantity of silanol side groups which will favour the dispersion of the materials in aqueous sols.

In the present paper, the structure and the physicochemical characteristics of three different talc-like phyllosilicates synthesised by a 
hydrothermal process at $160{ }^{\circ} \mathrm{C}, 260{ }^{\circ} \mathrm{C}$ and $350{ }^{\circ} \mathrm{C}$ (called $\mathrm{T}_{160}, \mathrm{~T}_{260}$ and $T_{350}$ respectively or $T_{x}$, where $x$ represent the hydrothermal synthesis temperature) were characterised by X-ray powder diffraction, nitrogen adsorption/desorption measurements, thermogravimetric and differential thermal analyses. The morphology of the synthetic particles before and after their incorporation in the sol-gel coating was examined using field emission-scanning electron microscopy (FE-SEM) and transmission electron microscopy (TEM). Finally, the influence of the particles on the barrier properties of the sol-gel coatings deposited on carbon steel was studied by electrochemical impedance spectroscopy.

\section{Materials and methods}

\subsection{Synthesis and characterization of talc-like phyllosilicates}

Talc-like phyllosilicates were synthesised as previously described [18]. Hexahydrated magnesium chloride $\left(\mathrm{MgCl}_{2} \cdot 6 \mathrm{H}_{2} \mathrm{O}\right)$, pentahydrated sodium metasilicate $\left(\mathrm{Na}_{2} \mathrm{SiO}_{3} \cdot 5 \mathrm{H}_{2} \mathrm{O}\right)$ and hydrochloric acid, used for the synthesis, were purchased from Aldrich. Natural talc, from the Trimouns deposit, located in the French Pyrénées, was used for comparison. Its composition is [19]: $\left[\mathrm{Mg}_{2.978} \mathrm{Fe}^{2+}{ }_{0.019} \mathrm{Mn}^{2+}{ }_{0.001} \mathrm{Fe}^{3+}{ }_{0.005} \mathrm{Al}_{0.007}\right]_{3}$ $\left[\mathrm{Si}_{3.984} \mathrm{Fe}^{3+}{ }_{0.004} \mathrm{Al}_{0.007}\right]_{4} \mathrm{O}_{10}(\mathrm{OH})_{1.952} \mathrm{~F}_{0.048}$.

$\mathrm{X}$-ray powder diffraction patterns were obtained using an INEL CPS 120 powder diffractometer (Ni-filtered Co-K $\alpha$ radiation, $\lambda=0.178897 \mathrm{~nm}$ ), between 0.293 and $107.274^{\circ} 2 \theta$ with a step size of $0.029^{\circ}$. Specific surface areas were determined by nitrogen adsorption/desorption measurements made at $77 \mathrm{~K}$, using a volumetric method, with a Micromeritics TriStar II 3020 apparatus. Nitrogen of high purity (99.999\% purchased from Aldrich) was used. The isotherms were recorded in the $0.008-0.994$ relative pressure range. Samples were outgassed for $10 \mathrm{~h}$ at $90{ }^{\circ} \mathrm{C}$ under vacuum before analysis. Thermogravimetric (TGA) and differential thermal (DTA) analyses were carried out on a Setaram TG-DTA 92 thermobalance using $20 \mathrm{mg}$ of product; $\alpha$-alumina was used as reference. The heating rate was $5{ }^{\circ} \mathrm{C} \mathrm{min}-1$, the temperature range was 20 to $1200{ }^{\circ} \mathrm{C}$, and the analyses were done using a $1.5 \mathrm{~L} \mathrm{~h}^{-1}$ air flow. FE-SEM observations of talc-like phyllosilicates were done on a JEOL JSM $6700 \mathrm{~F}$ operating at $3 \mathrm{kV}$. TEM observations were carried out on a JEOL 2010 microscope operating at $200 \mathrm{kV}$. Prior to observation, the powders were dispersed in ethanol and one droplet was deposited onto a carbon-coated copper grid and dried in air at room temperature.

\subsection{Preparation of sols}

Sols were prepared by addition of tetraethoxysilane (TEOS) and (3-(methacryloxy)propyl)triethoxysilane (MAP), purchased from Acros Organics, with a molar ratio [TEOS]/[MAP] of 8. Ethanol was used as solvent and water was added for the hydrolysis of TEOS and MAP. The molar ratio was 1/9/7 for (TEOS + MAP)/Ethanol/Water respectively. A plasticizer, polyethyleneglycol (PEG) 35000 purchased from Aldrich, was added to the sol to increase its viscosity. The concentration of PEG in the sol was $40 \mathrm{~g} \mathrm{~L}^{-1}$. The different constituents of the sol were added in the following order and volume percent: TEOS (23\%), MAP (3\%), ethanol (60\%) and aqueous solution of PEG (14\%). Then, the $\mathrm{pH}$ of the sol was adjusted to 4 by adding $62 \%$ nitric acid purchased from Acros Organics. $5 \mathrm{~g} \mathrm{~L}^{-1}, 10 \mathrm{~g} \mathrm{~L}^{-1}$ and $20 \mathrm{~g} \mathrm{~L}^{-1}$ of the different talc-like phyllosilicates were incorporated in the sol.

\subsection{Coating deposition and characterization}

XC35 carbon steel discs $\left(\mathrm{S}=5 \mathrm{~cm}^{2}\right)$ were used as substrates. The composition in weight percent was $\mathrm{C}=0.35, \mathrm{Mg}=0.65, \mathrm{Si}=0.25$, $\mathrm{P}=0.035, \mathrm{~S}=0.035$ and $\mathrm{Fe}=98.68$. The samples were polished with $\mathrm{SiC}$ carbon paper down to grade 1200 , successively rinsed with distilled water and ethanol and finally dried in warm air.
The films were applied by dip-coating: the carbon steel samples were dipped into the sol and withdrawn with a constant rate of $24 \mathrm{~cm} \mathrm{~min}{ }^{-1}$. Three successive deposits were performed. Between each deposition, samples were dried at $60{ }^{\circ} \mathrm{C}$ for $30 \mathrm{~min}$ and the same treatment was applied to the final coating for $20 \mathrm{~h}$. The dry film thickness was $6.5 \pm 0.5 \mu \mathrm{m}$ (measured by SEM). The thickness was both independent of the nature and of the concentration of the phyllosilicates. However, for the highest phyllosilicate concentration $\left(20 \mathrm{~g} \mathrm{~L}^{-1}\right)$, the presence of large aggregates modified the topography of the surface and locally increased the coating thickness up to $12 \mu \mathrm{m}$. It can be underlined that the aggregates were always embedded in the sol-gel coating.

SEM observations of the surface of the sol-gel coatings were performed using a JEOL JSM 6400. The cross-section of the carbon steel covered with the sol-gel coating was observed by FE-SEM on a JEOL JSM $6700 \mathrm{~F}$ operating at $3 \mathrm{kV}$.

For the electrochemical impedance measurements, a threeelectrode cell was used with a platinum counter-electrode, a saturated sulphate reference electrode and the carbon steel disc covered with the sol-gel coating as working electrode (exposed area of $7 \mathrm{~cm}^{2}$ ). The electrolytic solution was prepared from distilled water by adding $0.01 \mathrm{M} \mathrm{Na}_{2} \mathrm{SO}_{4}$ (reagent grade). This solution presents low aggressiveness and enabled better characterization of the barrier properties and minimised the corrosion attack of the carbon steel. The electrochemical cell was kept at room temperature and open to air, and impedance measured using a Biologic VSP device. The impedance diagrams were obtained under potentiostatic conditions at the corrosion potential over a frequency range of $60 \mathrm{kHz}$ to $10 \mathrm{mHz}$ with 6 points per decade, using a $10 \mathrm{mV}$ peak-to-peak sinusoidal voltage.

\section{Results}

\subsection{Structure and physicochemical characteristics of talc-like phyllosilicates}

X-ray powder diffraction patterns were obtained for the three $T_{x}$ talc-like phyllosilicates. They were compared to the natural talc diagram (Fig. 1). Each sample shows interreticular distances $d$ characteristic for (001), (002), (003) and (060) reflections of talc structure $[20,21]$. The (060) reflection was observed at $0.151 \mathrm{~nm}$ for $T_{160}$ and $0.152 \mathrm{~nm}$ for $\mathrm{T}_{260}$ and $\mathrm{T}_{350}$; the values are characteristic of a



Fig. 1. X-Ray powder diffraction patterns of $T_{x}$ talc-like phyllosilicates and of natural talc $\left({ }^{*} \mathrm{NaCl}\right)$; a.u.: arbitrary units. 
trioctahedral 2:1 phyllosilicate structure (in the octahedral sheets each $\mathrm{O}$ atom or $\mathrm{OH}$ group is surrounded by three divalent cations) $[22,23]$. The interlamellar distance was calculated with the (003) diffraction peak; the values were $0.945 \mathrm{~nm}, 0.942 \mathrm{~nm}$ and $0.941 \mathrm{~nm}$ for $\mathrm{T}_{160}, \mathrm{~T}_{260}$ and $\mathrm{T}_{350}$, respectively. The values are slightly higher compared to the natural talc structure $\left(\mathrm{d}_{(001)}=0.934 \mathrm{~nm}\right)$ [24]. The $\mathrm{T}_{160}$ and $\mathrm{T}_{260}$ samples presented relatively broad $(00 \mathrm{l})$ reflections whereas the $T_{350}$ sample exhibited a sharp peak that clearly separates from another less intense at a lower diffraction angle. The position, the shape and the intensity of the (001) reflection can be explained by the presence of stevensite sheets in the synthetic materials and indicates that the increase of the hydrothermal synthesis temperature led to the decrease of the proportion of stevensite. The hydrothermal synthesis temperature of $350^{\circ} \mathrm{C}$ gave rise to a mineral with characteristics closer to those of natural talc, confirmed by the presence of the characteristic (002) reflection. The three sharp peaks $(d=0.423 \mathrm{~nm}$, $0.333 \mathrm{~nm}$ and $0.280 \mathrm{~nm}$ ) on the X-ray powder diffraction patterns of $\mathrm{T}_{350}$ sample were assigned to $\mathrm{NaCl}$ crystals precipitated during the precursor synthesis which was not sufficiently washed for this sample.

The presence of the stevensite in the synthetic materials is responsible for different particle morphologies. Sheets of natural talc have angular shapes and are stacked on each other, leading to the formation of platelets. FE-SEM and TEM micrographs of $\mathrm{T}_{\mathrm{x}}$ samples are presented in Figs. 2 and 3 respectively. $\mathrm{T}_{160}$ particles have rounded edges and they are stacked in all space directions forming aggregates with non-platelet shapes. $T_{350}$ particles also have rounded edges but they
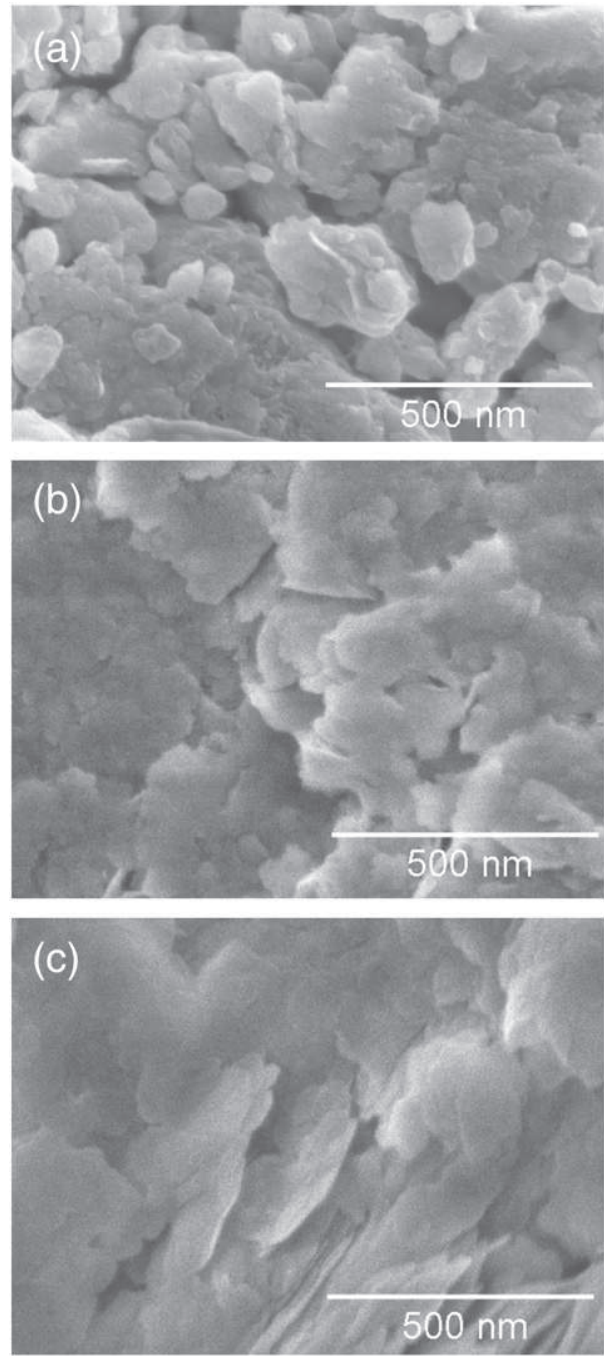

Fig. 2. FE-SEM micrographs for $\mathrm{T}_{160}$ (a), $\mathrm{T}_{260}$ (b) and $\mathrm{T}_{350}$ (c) talc-like phyllosilicates.
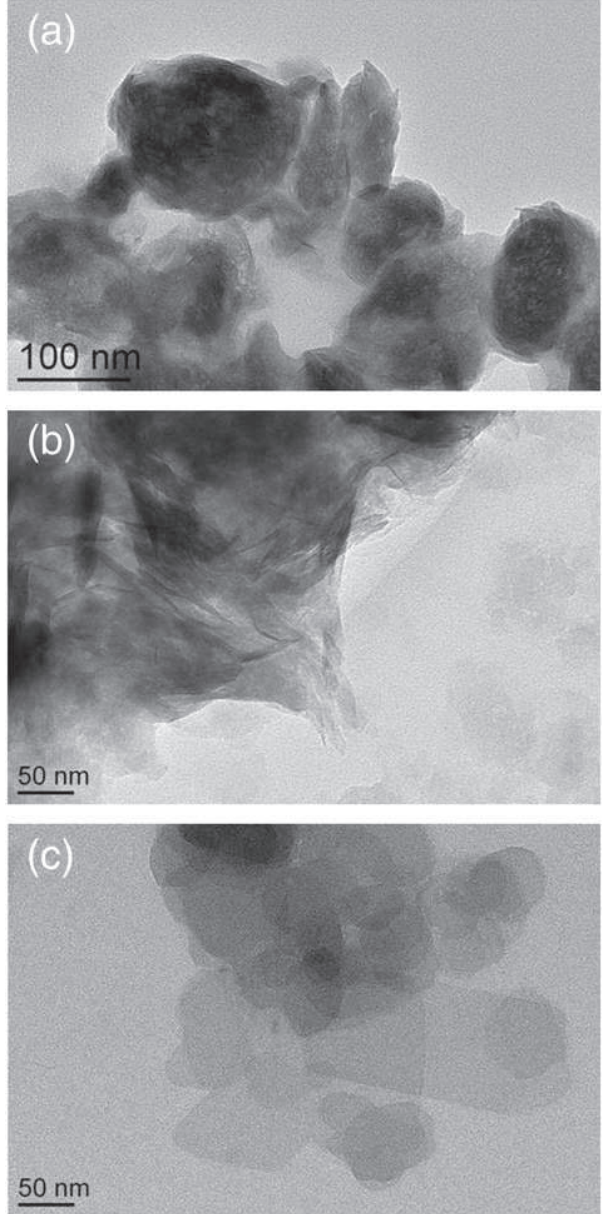

Fig. 3. TEM micrographs for $\mathrm{T}_{160}$ (a), $\mathrm{T}_{260}$ (b) and $\mathrm{T}_{350}$ (c) talc-like phyllosilicates.

are stacked along a single axis like natural talc particles. The arrangement of $T_{260}$ particles leads to a mixed structure of platelet and nonplatelet aggregates. TEM micrographs (Fig. 3 ) reveal large aggregates formed by the stacking of the particles but also isolated lamellar particles. Thus, depending on the hydrothermal synthesis temperature and according to the proportion of stevensite sheets, talc-like phyllosilicate particles are stacked in different ways as shown previously [18]. The particle size is about $200 \mathrm{~nm}$ for all the $T_{x}$ samples whereas natural talc particle size depends on where it comes from; nevertheless, it is always more than one micrometre. The small size of the synthesised particles is an advantage for their dispersion in aqueous sols because large particles would favour sedimentation rather than dispersion. The hydrophilic character is also an important parameter for the interactions between particles and aqueous sols. The decrease in the particle size contributes to greater edge area, mainly composed of hydrophilic and reactive silanol bonds, and thus to a more hydrophilic character of the $T_{x}$ materials which can be quantified by nitrogen adsorption/desorption measurements and thermogravimetric analyses, respectively.

The specific surface areas were calculated from nitrogen adsorption isotherms by applying the BET Equation [25] and are reported in Table 1. Specific surface areas vary from 544 to $126 \mathrm{~m}^{2} \mathrm{~g}^{-1}$ for $\mathrm{T}_{160}$

Table 1

Specific surface areas calculated from nitrogen adsorption/desorption measurements of natural talc and $\mathrm{T}_{\mathrm{x}}$ talc-like phyllosilicates.

\begin{tabular}{lllll}
\hline & $\mathrm{T}_{160}$ & $\mathrm{~T}_{260}$ & $\mathrm{~T}_{350}$ & $\mathrm{~T}_{\mathrm{N}}$ \\
\hline Specific surface area $\left(\mathrm{m}^{2} / \mathrm{g}\right)$ & 544 & 275 & 126 & 1 \\
\hline
\end{tabular}




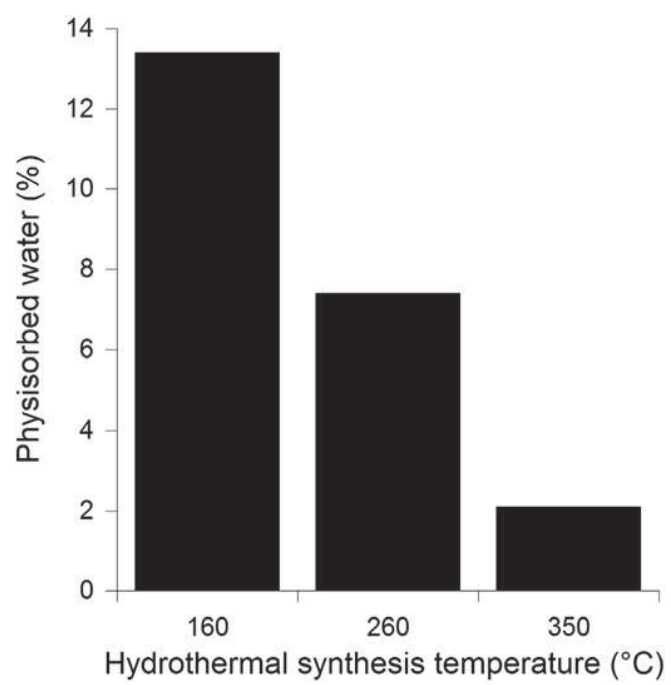

Fig. 4. Percentage of physisorbed water calculated from thermogravimetric data for the $\mathrm{T}_{\mathrm{x}}$ talc-like phyllosilicates. and $\mathrm{T}_{350}$, respectively. These values are significantly higher than the specific surface area of natural talc $\left(1 \mathrm{~m}^{2} \mathrm{~g}^{-1}\right)$ and can be explained by the larger quantity of silanol bonds in $T_{x}$ materials. Specific surface area depends on the hydrothermal synthesis temperature: the higher the temperature, the lower the specific surface area.

The hydrophilic character of the material can be shown by thermogravimetric analyses. Unlike the thermogram of natural talc, talclike phyllosilicate thermograms present a weight loss between $20^{\circ} \mathrm{C}$ and $140^{\circ} \mathrm{C}$ attributed to the loss of physisorbed water on the materials (thermograms not reported here). The percentages of physisorbed water for each $T_{x}$ material are presented in Fig. 4 . The results show that the hydration is lower when the hydrothermal synthesis temperature increases which is in agreement with the influence of the silanol bonds. The hydrophilic character of $T_{x}$ materials depends on the contribution of the lateral faces. The hydrophilic character associated to the small particle size will favour the dispersion of talclike phyllosilicates in aqueous sols.

\subsection{Coatings morphology}

Examples of SEM micrographs of the coating surfaces with different concentrations of $\mathrm{T}_{260}$ talc-like phyllosilicate are presented in Fig. 5. Similar results were obtained for the two other phyllosilicates.
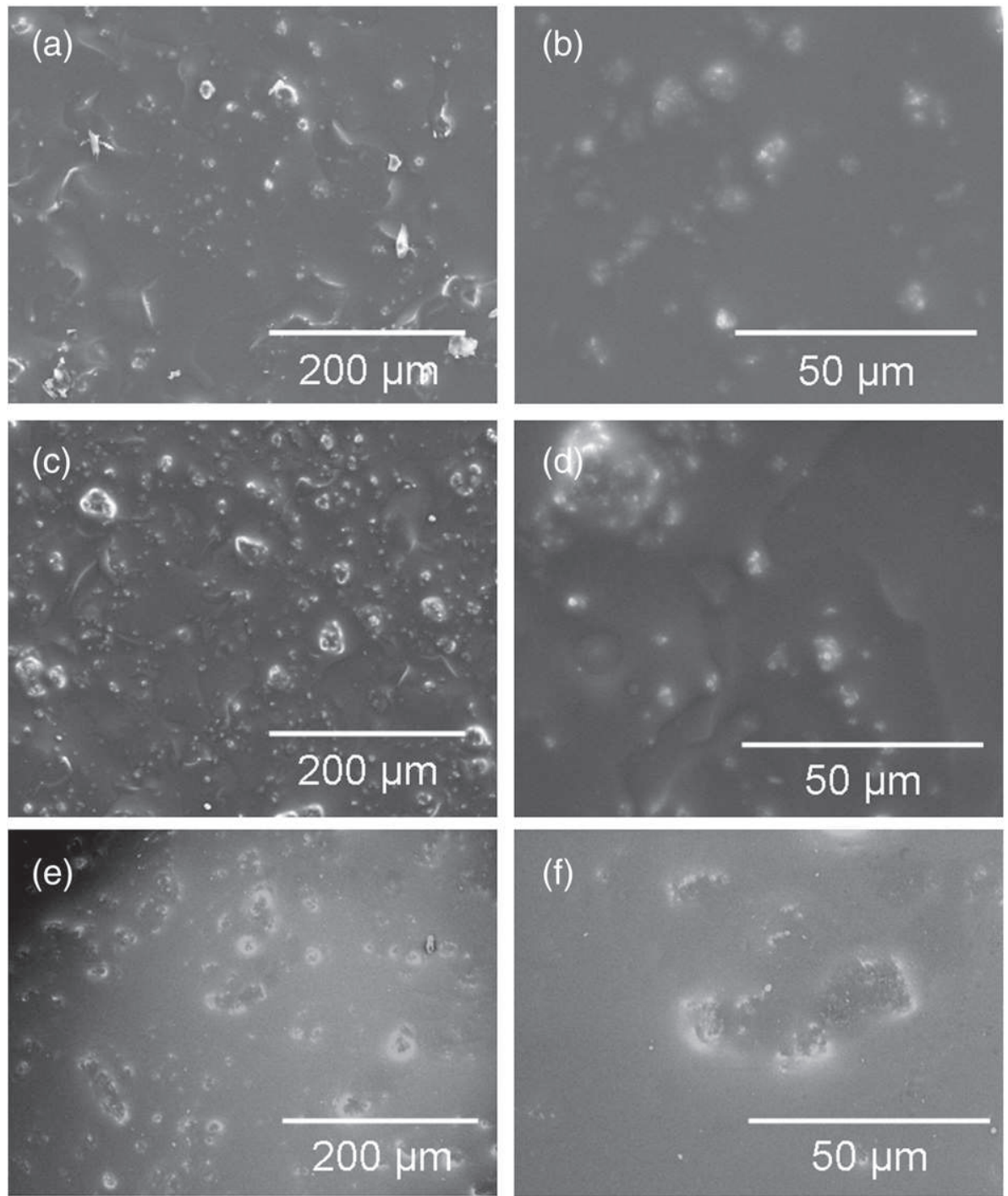

Fig. 5. SEM micrographs for the sol-gel films prepared by dispersion in the sol of $5 \mathrm{~g} \mathrm{~L}^{-1}$ (a) and (b), $10 \mathrm{~g} \mathrm{~L}^{-1}$ (c) and (d) and $20 \mathrm{~g} \mathrm{~L}^{-1}$ (e) and (f) of $\mathrm{T}_{260}$ talc-like phyllosilicates. 
The micrographs revealed a large quantity of aggregates. The increase of the particle concentration in the sol leads not only to an increase of the aggregate quantity in the coating but also to a higher disparity of aggregate size. The coating prepared from the sol with $5 \mathrm{~g} \mathrm{~L}^{-1}$ of $\mathrm{T}_{260}$ particles contained aggregates of $8 \mu \mathrm{m}$ whereas the sol with $20 \mathrm{~g} \mathrm{~L}^{-1}$ of $\mathrm{T}_{260}$ particles presented not only $8 \mu \mathrm{m}$ aggregates but also $45 \mu \mathrm{m}$ aggregates and isolated particles. FE-SEM observations of crosssections of the coatings prepared by dispersion of $20 \mathrm{~g} \mathrm{~L}^{-1}$ of natural talc and $\mathrm{T}_{260}$ talc-like phyllosilicate in the sol are presented in Fig. 6 . The coating prepared by dispersion of natural talc particles has a uniform thickness of $6.8 \mu \mathrm{m}$. The coating contains few particles but cracks of up to $4 \mu \mathrm{m}$ long can be observed. When the coating was deposited, the sedimentation of the large aggregates probably disturbed the formation of the sol-gel network and provoked the crack development. FE-SEM micrographs of the coating section containing $T_{260}$ particles show a heterogeneous thickness from about $6 \mu \mathrm{m}$ to $12 \mu \mathrm{m}$. Nevertheless, the thickness is lower than the aggregate size of $45 \mu \mathrm{m}$ previously observed. Through the whole coating thickness, talc-like phyllosilicate platelets form aggregates with a size of about $4 \mu \mathrm{m}$. Hence, aggregates are much longer than wide and they are arranged parallel to the metal surface. In spite of the aggregate length, the incorporation of talc-like phyllosilicates does not induce cracks in the coating owing to the better dispersion in the sol.

\subsection{Effect of the particles on the barrier properties of sol-gel coatings}

The influence of natural talc and synthetic materials on the barrier properties of the coating was evaluated by electrochemical impedance measurements. The natural talc and the three talc-like phyllosilicates $T_{160}, T_{260}$ and $T_{350}$ were dispersed in the sol with a concentration of $10 \mathrm{~g} \mathrm{~L}^{-1}$. The impedance diagrams obtained after immersion for $2 \mathrm{~h}$ in a $0.01 \mathrm{Na}_{2} \mathrm{SO}_{4}$ solution for the sol-gel coatings with the different talc-like phyllosilicates are compared with the diagram obtained for the steel covered with the particle-free sol-gel coating (Fig. 7). The diagrams are characterised by two capacitive loops: the first one is attributed to the barrier properties of the coating and the second one to the corrosion process. The diagrams can be analysed by the equivalent circuit frequently used to represent porous coatings (Fig. 8) [26]. Parameters $\alpha$ and $Q$ introduced in the equivalent circuit, are associated to a constant phase element (CPE) to take into account the non-ideal behaviour of the interface [27]. They were graphically obtained as [28]

$$
\begin{aligned}
& \alpha=-\frac{d \log \left(-Z_{j}\right)}{d \log (f)} \\
& Q=\sin \left(\frac{\alpha \pi}{2}\right) \frac{-1}{Z_{j}(2 \pi f)^{\alpha}} .
\end{aligned}
$$

The parameters of the different systems are reported in Table 2. $\alpha_{d l}$ and $Q_{d l}$ characterise the electrochemical processes which occur on the metal surface at the bottom of the pores. For the coating without particles, the low value of $R_{f}$ reflects a high porosity of the film which allows a rapid penetration of the electrolyte. The value of $\alpha_{f}(0.76)$ is far from unity which could be attributed to heterogeneous properties of the coating. The poor corrosion resistance of the system is highlighted by the low polarisation resistance $\left(R_{p}\right)$ which is about $6000 \Omega \mathrm{cm}^{2}$. The coating without particles was seen to peel off quickly inducing rapid corrosion development.

It must be underlined that the impedance diagram obtained for the coating containing natural talc (not reported here) was similar to that obtained on the bare carbon steel. The HF capacitive loop, characteristic of the coating was not observed and the polarisation resistance was low (about $400 \Omega \mathrm{cm}^{2}$ ). This was attributed to the presence of cracks in the coating which favoured the penetration of the electrolyte in the film. The incorporation of $\mathrm{T}_{160}$ decreased the barrier properties by comparison with the sol-gel without particles. $T_{160}$ phyllosilicate contained a significant proportion of stevensite sheets and the shape of the aggregates was detrimental to the barrier effect of the coating. Moreover, the thermogravimetric analysis revealed a proportion of physisorbed water of $13.4 \%$ (Fig. 4). Thus, the strong hydrophilic character allows easier penetration of the electrolyte through the coating due to the affinity of water of the particles. The barrier properties of the coating can be improved by decreasing the particle concentration. This was confirmed with a concentration of $1 \mathrm{~g} \mathrm{~L}^{-1}$. On the impedance diagrams (not shown), the film resistance was 4 times as high as the resistance obtained for the coating prepared with $10 \mathrm{~g} \mathrm{~L}^{-1}$ of particles in the sol. The incorporation of particles
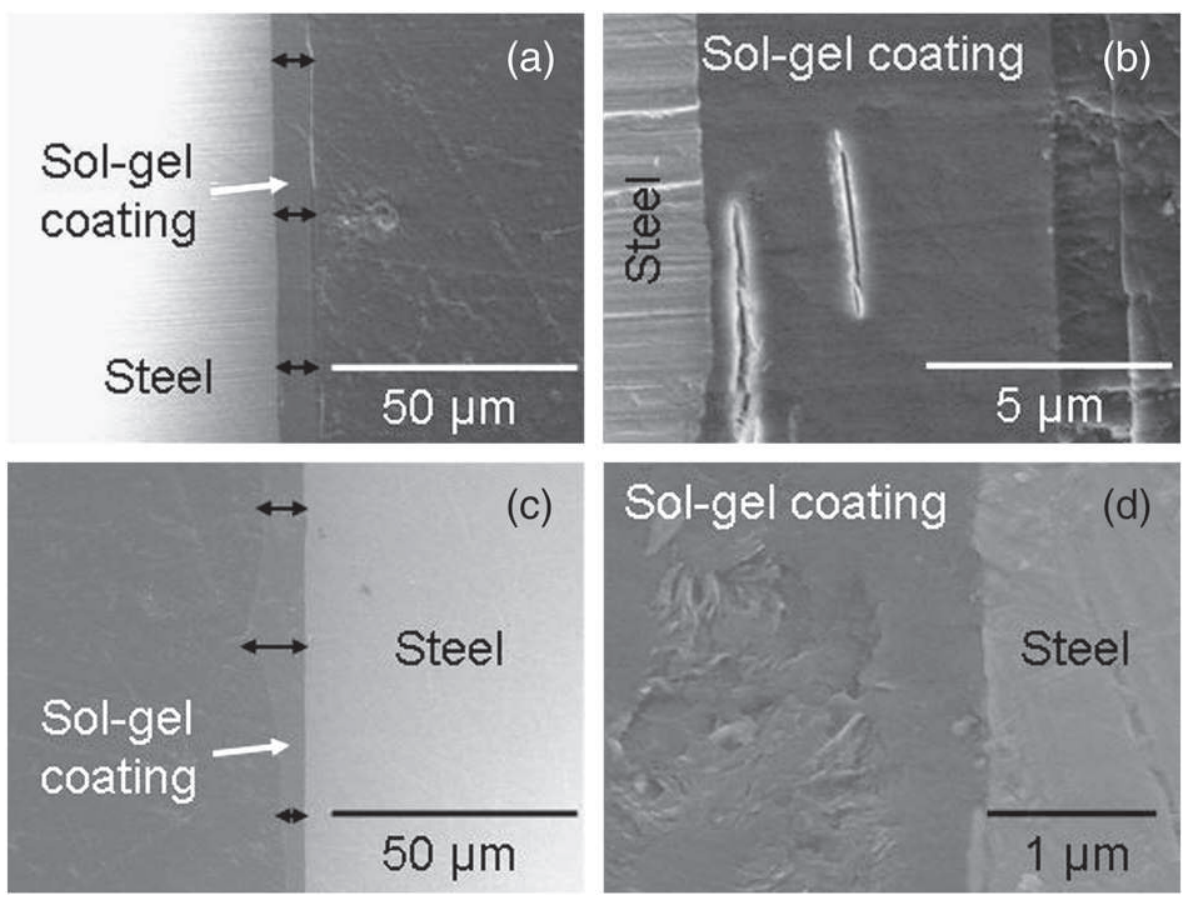

Fig. 6. FE-SEM micrographs for the sol-gel film prepared by dispersion in the sol of $20 \mathrm{~g} \mathrm{~L}^{-1}$ of natural talc (a and b) and $\mathrm{T}_{260}$ talc-like phyllosilicate (c and d). 

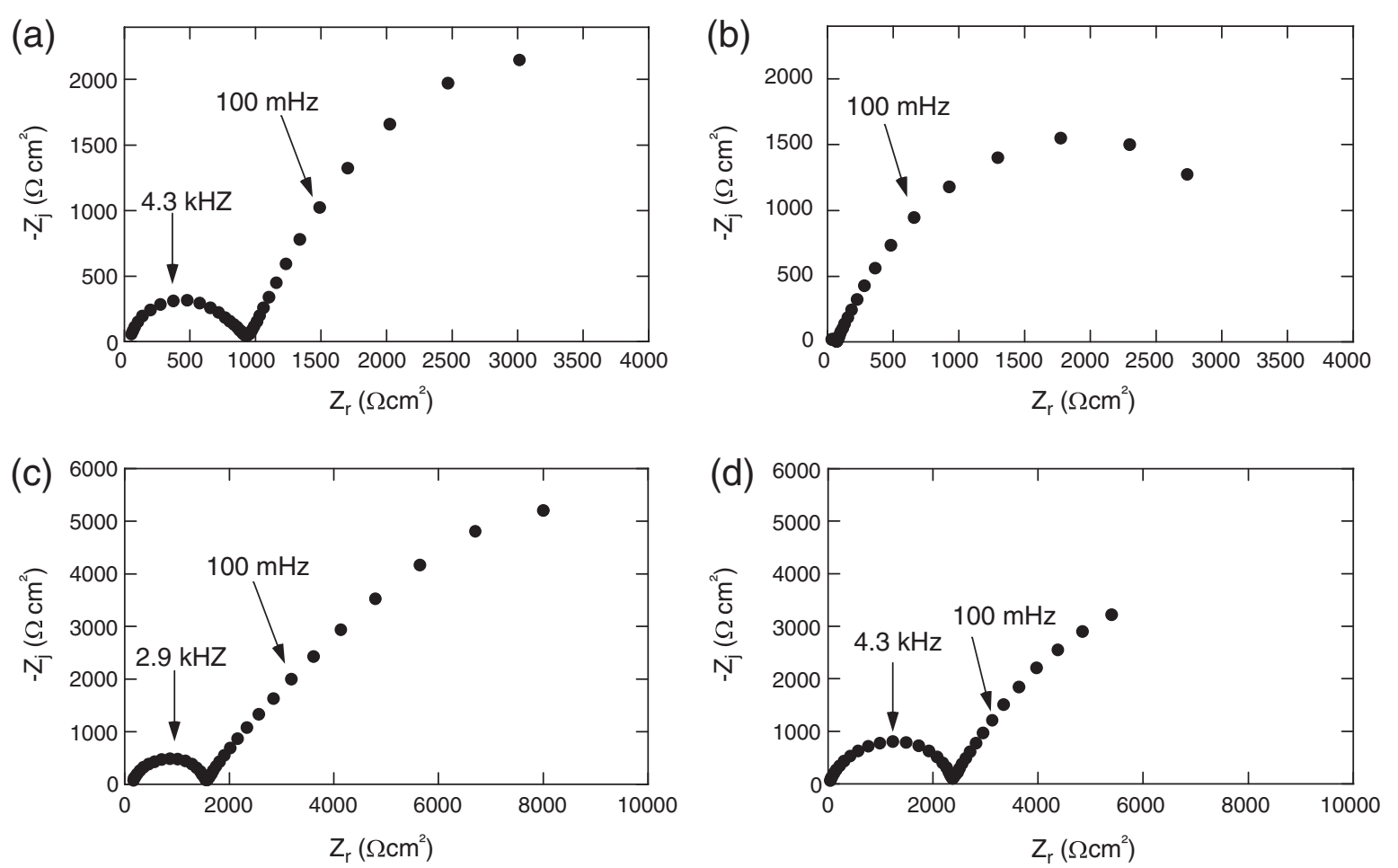

Fig. 7. Electrochemical impedance diagrams (Nyquist representation) obtained after immersion for $2 \mathrm{~h}$ in the $0.01 \mathrm{M} \mathrm{Na}_{2} \mathrm{SO}_{4}$ solution for the carbon steel electrode coated with the sol-gel films without particles (a), and prepared by dispersion in the sol of $10 \mathrm{~g} \mathrm{~L}^{-1}$ of $\mathrm{T}_{160}$ (b), $\mathrm{T}_{260}$ (c) and $\mathrm{T}_{350}$ (d) talc-like phyllosilicates.

slightly increased film resistance from $980 \Omega \mathrm{cm}^{2}$ with particle-free film to $1500 \Omega \mathrm{cm}^{2}$ and $2300 \Omega \mathrm{cm}^{2}$ with $\mathrm{T}_{260}$ and $\mathrm{T}_{350}$ respectively (Table 2). Both the structure, close to that of natural talc, and the weaker hydrophilic character of these materials improved the barrier properties. As a consequence, the corrosion protection was enhanced by the incorporation of $\mathrm{T}_{260}$ and $\mathrm{T}_{350}$ particles. $R_{p}$ increased from $6000 \Omega \mathrm{cm}^{2}$ without to $20,000 \Omega \mathrm{cm}^{2}$ and $10,000 \Omega \mathrm{cm}^{2}$ with $\mathrm{T}_{260}$ and $\mathrm{T}_{350}$ respectively (Table 2).

The influence of particle concentration was investigated for $T_{260}$. $5 \mathrm{~g} \mathrm{~L}^{-1}$ and $20 \mathrm{~g} \mathrm{~L}^{-1}$ of particles were incorporated into the sol. The impedance diagrams were compared to that obtained for the coating prepared with $10 \mathrm{~g} \mathrm{~L}^{-1}$ of particles in the sol (Fig. 9). When the particle concentration was increased, the size of the high frequency loop also increased. The $R_{f}$ value was about $10,000 \Omega \mathrm{cm}^{2}$ for $20 \mathrm{~g} \mathrm{~L}^{-1}$ whereas it was only of $280 \Omega \mathrm{cm}^{2}$ for $5 \mathrm{~g} \mathrm{~L}^{-1}$. The high particle concentration induced tortuous pathways in the coating slowing down the penetration of the electrolyte hence improving the barrier properties. Moreover, $\mathrm{T}_{260}$ particles have a significant hydrophobic character (even if it is lower than that of natural talc) and its incorporation into the coating modifies the hydration process and the diffusion of corrosive species. The increase of the talc-like phyllosilicate concentration also induced an increase of $\alpha_{f}$ and a decrease of $Q_{f}$ values

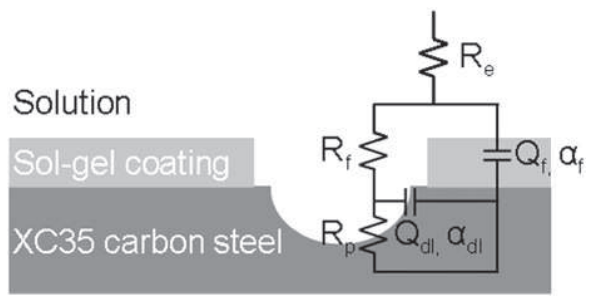

Fig. 8. Schematic representation of the carbon steel/sol-gel coating interface and equivalent circuit: $R_{e}$ : electrolyte resistance / $R_{f}$ : resistance of the solution in the pores of the coating / $Q_{f}$ and $\alpha_{f}$ : parameters of the CPE associated to the sol-gel film / $R_{p}$ : polarisation resistance / $Q_{d l}$ and $\alpha_{d l:}$ parameters of the CPE associated to the corrosion process at the bottom of the pores.
(Fig. 10). These variations confirm the lower water penetration and thus the improvement of the barrier properties. It can be mentioned that the barrier efficiency of the different systems tested here was relatively low even after only $2 \mathrm{~h}$ of immersion which is not satisfactory for the anticorrosion performance but which is helpful in rapidly discriminating the effect of introducing phyllosilicates in the sol-gel matrix. It was pointed out that for an epoxy coating with a high barrier resistance it was difficult to reveal the difference in corrosion resistance brought about by the introduction of clay [7].

The changes in the barrier properties influenced the corrosion process. The polarisation resistance increased with the particle concentration indicating a lower corrosion rate. In spite of the loss of the barrier properties for a concentration of $5 \mathrm{~g} \mathrm{~L}^{-1}$, which can be explained by a high heterogeneity and limited tortuous pathways, the $R_{p}$ value $\left(\sim 10,000 \Omega \mathrm{cm}^{2}\right)$ was higher than that obtained for the system without particles $\left(\sim 6000 \Omega \mathrm{cm}^{2}\right)$. For a higher particle concentration $\left(20 \mathrm{~g} \mathrm{~L}^{-1}\right)$, the diagram was characterised by a linear part at low frequencies and the $\alpha_{d l}$ value (0.48) suggests that diffusion occurs through the coating. After immersion for $2 \mathrm{~h}$, the coating had not peeled off and thus, the increase of the polarisation resistance can also be explained by a favourable modification of the coating/substrate interface with the incorporation of particles.

\section{Discussion}

The small size of the talc-like phyllosilicate particles compared to that of natural talc and their hydrophilic character allowed a better dispersion in the sol. As a consequence, the coatings were more homogeneous, which is essential to obtain interesting barrier properties. The increase of particle concentration leads to a decrease of $Q_{f}$, the capacity of the electrolyte to penetrate the coating goes down owing to the increase of the tortuosity and/or the densification of the coating due to the presence of the particles. The improvement of the barrier properties and hence of corrosion protection may also be due to interactions between the particles, the sol-gel network and the metal. The adhesion of the sol-gel coating on the metal 
Table 2

Parameters obtained from the impedance diagrams for the carbon steel covered by sol-gel films prepared by dispersion in the sol of $10 \mathrm{~g} \mathrm{~L}^{-1}$ of $\mathrm{T}_{\mathrm{x}}$ talc-like phyllosilicates. For comparison, parameters obtained for the sol-gel without particles are reported.

\begin{tabular}{cclllll}
\hline & $\begin{array}{l}R_{f} \\
\left(\Omega \mathrm{cm}^{2}\right)\end{array}$ & $\begin{array}{l}Q_{f} \\
\left(\Omega^{-1} \mathrm{~cm}^{-2} s^{\alpha}\right)\end{array}$ & $\alpha_{f}$ & $\begin{array}{l}R_{p} \\
\left(\Omega \mathrm{cm}^{2}\right)\end{array}$ & $\begin{array}{l}Q_{d l} \\
\left(\Omega^{-1} \mathrm{~cm}^{-2} s^{\alpha}\right)\end{array}$ & $\alpha_{d l}$ \\
\hline $\begin{array}{l}\text { Without } \\
\text { particles }\end{array}$ & 980 & $13810^{-9}$ & 0.76 & $\sim 6000$ & $2410^{-6}$ & 0.67 \\
$\mathrm{~T}_{160}$ & 55 & $/$ & & & & \\
$\mathrm{T}_{260}$ & 1500 & $1910^{-9}$ & 0.70 & $\sim 20,000$ & $9710^{-6}$ & 0.71 \\
$\mathrm{~T}_{350}$ & 2300 & $3210^{-9}$ & 0.68 & $\sim 10,000$ & $1810^{-6}$ & 0.58 \\
\hline
\end{tabular}

substrate is due to the formation of chemical bonds between the silanol groups of hydrolyzed TEOS and MAP and iron hydroxides on the steel substrate according to the simplified reaction [29]:

$\mathrm{Si}-\mathrm{OH}_{\text {Solution }}+\mathrm{Fe}-\mathrm{OH}_{\text {substrate }} \rightarrow \mathrm{Si}-\mathrm{O}-\mathrm{Fe}_{\text {Interface }}+\mathrm{H}_{2} \mathrm{O}$.

The size of the talc-like phyllosilicate platelets is greatly reduced compared to natural talc and thus the contribution of the lateral


Fig. 9. Electrochemical impedance diagrams (Nyquist representation) obtained after immersion for $2 \mathrm{~h}$ in the $0.01 \mathrm{M} \mathrm{Na}_{2} \mathrm{SO}_{4}$ solution for the carbon steel electrode coated with sol-gel films prepared by dispersion in the sol of $5 \mathrm{~g} \mathrm{~L}^{-1}$ (a), $10 \mathrm{~g} \mathrm{~L}^{-1}$ (b) and $20 \mathrm{~g} \mathrm{~L}^{-1}$ (c) of $\mathrm{T}_{260}$ talc-like phyllosilicates.
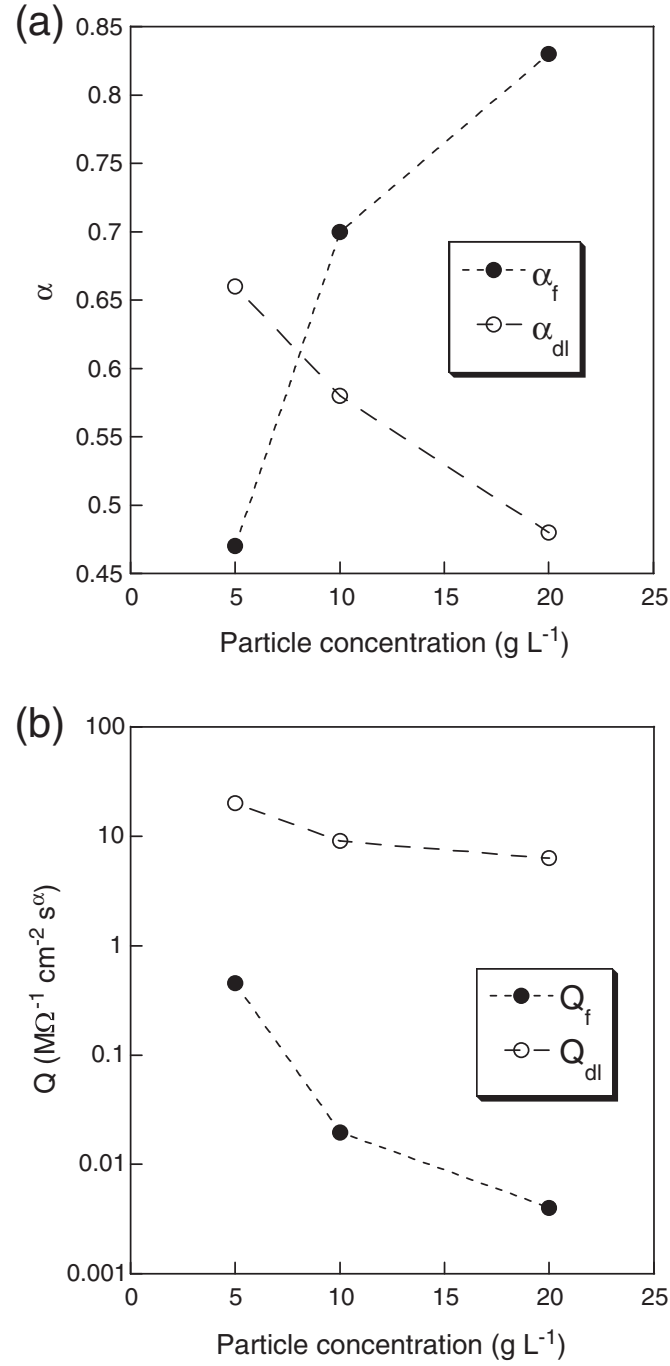

Fig. 10. Variation of $\alpha$ (a) and $Q$ (b), obtained from impedance data, with different particle concentrations in the sols.

faces is greater, as pointed out by their larger specific surface area. Lateral faces contain silanol bonds $(\mathrm{Si}-\mathrm{OH})$ which may not only interfere during the formation of the sol-gel network but also during the adhesion to the metal substrate. The improvement of the adhesion of the sol-gel coating after the incorporation of hydrotalcite was shown by pull-off test in a study by Alvarez et al. [29]. According to the authors, hydrotalcite has a large number of hydroxyl groups on the surface and between the sheets which form chemical bonds with the metal. Hence, the silanol groups of talc-like phyllosilicates may form bonds not only with hydrolyzed TEOS and MAP but also with the iron hydroxides on the substrate and increase both the adhesion to the carbon steel and the cohesion of the sol-gel network. High particle concentrations increase the available number of silanol groups, and, as a consequence, the coating is denser and adherent to the carbon steel substrate. These two parameters favour a better barrier effect and improved corrosion resistance.

\section{Conclusions}

In the present study, SEM observations and electrochemical characterizations of different sol-gel coatings were performed to investigate correlations between the characteristics of talc-like phyllosilicates and their influence when incorporated into sol-gel coatings. The size, the hydrophilic character and the specific surface area of talc-like phyllosilicates, compared to that of natural talc, contribute to the improvement 
of the barrier properties of the sol-gel coating under certain conditions. A sufficient quantity of particles must be incorporated to create numerous tortuous pathways, the stacked particles must be platelets and the hydrophilic character must be low in order to avoid affinities with water. Coatings with at least $10 \mathrm{~g} \mathrm{~L}^{-1}$ of talc-like phyllosilicates synthesised at $260^{\circ} \mathrm{C}$ or $350^{\circ} \mathrm{C}$ present the more interesting barrier properties. First, the better dispersion of the materials in the sol compared to the dispersion of natural talc leads to a good distribution of a large number of particles in the coating which induces numerous tortuous pathways. Then, the hydrophobic character of the particles represents a barrier for the hydration of the coating. Finally, favourable interactions between the particles, the sol-gel network and the substrate can also explain the better corrosion protection.

\section{References}

[1] P. Galliano, J.J. Damborena, M.J. Pascual, A. Duran, J. Sol-Gel. Sci. Technol. 13 (1998) 723.

[2] D.C.L. Vasconcelos, J.A.N. Carballo, M. Mantel, W.L. Vasconcelos, J. Non-Cryst. Solids 273 (2000) 135

[3] S. Ono, H. Tsuge, Y. Nishi, S.I. Hirano, J. Sol-Gel. Sci. Technol. 29 (2004) 147.

[4] W.J. van Ooij, D. Zhu, M. Stacy, A. Seth, T. Mugada, J. Gandhi, P. Puomi, Tsinghua Sci. Technol. 10 (2005) 639.

[5] D. Wang, G.P. Bierwagen, Prog. Org. Coat. 64 (2009) 327.

[6] G. Gorrasi, M. Tortora, V. Vittoria, E. Pollet, B. Lepoitevin, M. Alexandre, P. Dubois, Polymer 44 (2003) 2271.

[7] C. Chen, M. Khobaib, D. Curliss, Prog. Org. Coat. 47 (2003) 376.

[8] T.T.X. Hang, T.A. Truc, T.H. Nam, V.K. Oanh, J.-B. Jorcin, N. Pébère, Surf. Coat. Technol. 201 (2007) 7408.
[9] T.A. Truc, T.T.X. Hang, V.K. Oanh, E. Dantras, C. Lacabanne, D. Oquab, N. Pébère, Surf. Coat. Technol. 202 (2008) 4945.

[10] M.-G. Olivier, M. Fedel, V. Sciamanna, C. Vandermiers, C. Motte, M. Poelman, F. Deflorian, Prog. Org. Coat. 72 (2011) 15.

[11] D.J. Sekelik, E.V. Stepanov, S. Nazarenko, D. Schiraldi, A. Hiltner, E. Baer, J. Polym. Sci., Part B: Polym. Phys. 27 (1998) 84

[12] P. Mederic, M. Moan, M.-H. Klopffer, Y. Saint-Gerard, Appl. Rheol. 13 (2003) 297

[13] L. Clerc, L. Ferry, E. Leroy, J.M. Lopez-Cuesta, Polym. Degrad. Stab. 88 (2005) 504

[14] J.H. Rayner, G. Brown, Clays Clay Miner. 21 (1973) 103.

[15] R.F. Giese, Clays Clay Miner. 27 (1979) 213.

[16] K.E. Bremmell, J. Addai-Mensah, J. Colloid Interface Sci. 283 (2005) 385.

[17] F. Martin, J. Ferret, C. Lebre, S. Petit, O. Grauby, J.-P. Bonino, D. Arseguel, A. Decarreau, C. Ferrage, Fr. Pat. FR 2006/06473, PCT/FR 2007/001200.

[18] K. Chabrol, M. Gressier, N. Pébère, M.-J. Menu, F. Martin, J.-P. Bonino, C. Marichal, J. Brendlé, J. Mater. Chem. 20 (2010) 9695.

[19] F. Martin, P. Micoud, L. Delmotte, C. Marichal, R. Le Dred, P. de Parseval, A. Mari, J.-P. Fortuné, S. Salvi, D. Béziat, O. Grauby, J. Ferret, Can. Mineral. 37 (1999) 997.

[20] I.S. Stemple, G.W. Brindley, J. Am. Ceram. Soc. 43 (1960) 34

[21] E. Ferrage, G. Seine, A.-C. Gaillot, S. Petit, P. de Parseval, A. Boudet, B. Lanson, J. Ferret, F. Martin, Eur. J. Mineral. 18 (2006) 483.

[22] S.L. Burkett, A. Press, S. Mann, Chem. Mater. 9 (1997) 1071.

[23] M. Jaber, J. Miéhé-Brendlé, L. Delmotte, R. Le Dred, Solid State Sci. 7 (2005) 610

[24] JCPDS Card Number 13-0558.

[25] S. Brunauer, P. Hemmet, E. Teller, J. Am. Ceram. Soc. 60 (1938) 309.

[26] L. Beaunier, I. Epelboin, J.C. Lestrade, H. Takenouti, Surf. Technol. 4 (1976) 237.

[27] G.J. Brug, A.L.G. van den Eeden, M. Sluyters-Rehbach, J.H. Sluyters, J. Electroanal. Chem. 176 (1984) 275

[28] M.E. Orazem, N. Pébère, B. Tribollet, J. Electrochem. Soc. 153 (2006) B129.

[29] D. Álvarez, A. Collazo, M. Hernández, X.R. Nóvoa, C. Pérez, Prog. Org. Coat. 68 (2010) 91. 